\title{
Pola Produksi Telur Puyuh yang Diberi Ransum Disuplementasi Betain dan Metionin
}

\author{
Adi Ratriyanto \\ Program Studi Peternakan, Fakultas Pertanian, Universitas Sebelas Maret \\ Corresponding author: ratriyanto@staff.uns.ac.id
}

\begin{abstract}
This study investigated the egg production pattern at the onset of lay until peak production in Japanese quails (Coturnix coturnix japonica) fed diet supplemented with betaine and methionine. Three hundred laying quails were randomly allocated to three groups of supplementations with 5 replicates of 20 quails. The three groups of treatments included basal diet (Control) or basal diet supplemented with 1.2 $\mathrm{g}$ betaine and $1.2 \mathrm{~g}$ methionine per $\mathrm{kg}$ diet. During onset of lay until $50 \%$ egg production (6 to 9 weeks of age), all groups were fed a basal diet, while the supplements were applied after 9 weeks. The egg production data were analyzed with analysis of variance and followed by Duncan's test for significant results. During week 6 to 9, all groups of quails generated similar egg production since they received the basal diet. On the later phase, supplementation of betaine and methionine enhanced average weekly egg production $(P<0.05)$ starting from week 10 compared with those without supplementation. The egg production curves indicated that production rapidly reached $60 \%$ soon after the onset of lay. Then, egg production rose sharply and reached the peaks of more than $80 \%$, indicating good egg production patterns. Supplementation of betaine and methionine enhanced the average overall and peak production $(P<0.01)$ without affecting the age at peak production. In addition, there were positive correlations between average of overall production and peak production of all treatments. It can be concluded that supplementation of betaine and methionine enhanced egg production in quails.
\end{abstract}

Keywords: Onset of lay; Peak production; Production curve; Quails

Cite this as: Ratriyanto, A. 2018. Pola Produksi Telur Puyuh yang Diberi Ransum Disuplementasi Betain dan Metionin. Caraka Tani: Journal of Sustainable Agriculture. 33(1), 1-7. doi:http://dx.doi.org/10.20961/carakatani.v33i1.19354

\section{PENDAHULUAN}

Puyuh merupakan penghasil telur yang potensial dan sudah banyak diternakkan secara intensif, terutama di Jepang dan Asia Tenggara (Kaye et al., 2017). Produksi telur puyuh meningkat secara cepat setelah peneluran pertama hingga mencapai puncak produksi selama beberapa minggu, kemudian menurun secara bertahap sampai akhir masa produksi (Narinc et al., 2013; Pavlidis et al., 2002). Puyuh mulai bertelur antara umur 35-42 hari (Kaye et al., 2017) dan dapat menghasilkan 250-300 butir telur dalam waktu satu tahun (Narinc et al., 2013). Selain itu, puyuh dapat mencapai puncak produksi pada umur sekitar 90 hari dengan produksi di atas 88\% (Narinc et al., 2013).

Produksi telur ditentukan oleh jumlah telur dalam satu clutch (jumlah telur dalam hari yang berurutan) dan periode diantara clutch pada saat tidak terjadi oviposisi (istirahat bertelur). Jumlah telur dalam clutch dipengaruhi oleh siklus circardian yang mensinkronkan antara ritme oviduct dan periode istirahat bertelur (Sadeghi et al., 2013). Meskipun pola produksi telur ditentukan oleh faktor genetik, tetapi masih dapat dimodifikasi dengan faktor lingkungan seperti nutrisi dan pencahayaan (Pavlidis et al., 2002). Tingginya produksi telur pada puyuh dapat merepresentasikan tingkat metabolisme akibat adanya modifikasi, misalnya dari faktor nutrisi (Kaye et al., 2017). Produksi telur dapat ditingkatkan melalui pendekatan nutrisi, salah satunya yaitu dengan suplementasi bahan aditif, misalnya metionin dan betain yang memiliki kesamaan fungsi yaitu sebagai donor gugus metil/ $\mathrm{CH}_{3}$ (Attia et al., 2016).

Betain dan metionin merupakan bahan aditif yang dapat disuplementasikan untuk memperbaiki status nutrisi ternak. Kedua bahan 
tersebut merupakan donor gugus metil dalam sintesis S-adenosil metionin (SAM). Gugus metil harus terpenuhi dari pakan karena tidak dapat disintesis di dalam tubuh ternak unggas (Ratriyanto et al., 2009). Selain sebagai donor gugus metil, metionin merupakan asam amino esensial yang diperlukan untuk sintesis protein dan respon imunitas (Metzler-Zebeli et al., 2009). Akan tetapi peran metionin untuk sintesis protein dan sebagai donor metil berkompetisi terhadap metionin yang tersedia, sehingga diperlukan alternatif donor metil lain (misalnya betain) yang dapat mensubtitusi metionin dan mengoptimalkan fungsi metionin untuk sintesis protein (Ratriyanto et al., 2009). Betain juga memiliki fungsi sebagai osmolit organik bagi sel maupun mikroflora saluran pencernaan sehingga dapat memperbaiki kecernaan nutrien dan pada akhirnya menghasilkan performa ternak yang optimal (Metzler-Zebeli et al., 2009).

Studi mengenai suplementasi betain dan metionin sudah dilakukan pada unggas. Suplementasi 0,5 sampai 1,2 g/kg metionin dalam ransum dapat meningkatkan produksi telur puyuh (Memon et al., 2003; Ratriyanto et al., 2017a). Hal yang sama juga diamati pada suplementasi betain, misalnya suplementasi $1 \mathrm{~g} / \mathrm{kg}$ betain meningkatkan produksi telur ayam sebesar $6 \%$ (Ezzat et al., 2011). Selain itu, suplementasi betain dapat mempertahankan performa pada puncak produksi ayam petelur yang diberi pakan rendah metionin (Hruby et al., 2005). Akan tetapi masih ada keterbatasan informasi mengenai suplementasi betain dan metionin terhadap pola produksi telur, khususnya pada puyuh. Oleh karena itu penelitian ini bertujuan untuk mengkaji pola produksi telur dari awal produksi sampai puncak produksi pada puyuh (Coturnix coturnix japonica) yang diberi suplementasi betain dan metionin.

\section{METODE PENELITIAN}

\section{Desain Penelitian}

Penelitian menggunakan 300 ekor puyuh betina petelur (Coturnix coturnix japonica) yang berumur 25 hari dengan bobot badan awal ratarata $81,62 \pm 1,76 \mathrm{~g}$. Penelitian ini dilakukan secara eksperimental menggunakan rancangan acak lengkap pola searah dengan 3 perlakuan, tiap perlakuan terdiri dari 5 ulangan, masing-masing
20 ekor puyuh. Perlakuan yang diberikan berupa tanpa suplementasi (Kontrol), suplementasi 1,2 g betain (betaine hydrochloride 96\%) dan suplementasi 1,2 g metionin ( $D L$-methionine 99\%) per kg ransum.

\section{Ransum Perlakuan}

Ransum yang digunakan selama perlakuan dalam penelitian ini mengandung protein sebesar $187 \mathrm{~g} / \mathrm{kg}$ dan energi metabolis $2.800 \mathrm{kcal} / \mathrm{kg}$. Sementara itu nutrien lain yang dibutuhkan oleh puyuh diformulasikan sesuai rekomendasi Nutrition Research Council (1994). Ransum basal diformulasikan dengan komponen utama jagung kuning dan bungkil kedelai (Tabel 1). Ransum perlakuan diperoleh dengan suplementasi yang dilakukan dengan cara menukar (expense) bekatul dengan betain dan metionin (Ratriyanto et al., 2017b).

\section{Pengambilan Data}

Kandang dibersihkan kemudian dilakukan desinfeksi dan pengapuran lantai kandang untuk mematikan mikroorganisme. Tempat pakan dan minum dicuci dalam larutan antiseptik kemudian dijemur di bawah sinar matahari sampai kering. Penentuan kandang dilakukan secara acak yaitu dengan melakukan pengundian. Puyuh ditempatkan dalam 15 unit kandang koloni dengan ukuran panjang $120 \mathrm{~cm}$, lebar $30 \mathrm{~cm}$ dan tinggi $25 \mathrm{~cm}$.

Ransum grower komersial diberikan pada puyuh berumur 25-39 hari, selanjutnya pada umur 40-41 hari puyuh diberi campuran ransum grower dan ransum basal dengan perbandingan 50:50\% dengan tujuan agar puyuh mampu menyesuaikan dengan ransum basal. Selanjutnya ransum basal diberikan mulai umur 42 hari. Pemberian ransum perlakuan dengan suplementasi betain dan metionin diberikan setelah produksi telur mencapai $50 \%$. Pemberian ransum dilakukan dua kali sehari yaitu pada pukul 07.00 dan 13.30, sedangkan air minum diberikan secara ad libitum. Peubah yang diamati adalah rata-rata produksi telur mingguan dan produksi telur pada hari tertentu (test day) tiap minggu. Produksi telur dihitung setiap hari dan dinyatakan dalam hen day production, yaitu persentase jumlah telur yang dihasilkan dibandingkan dengan jumlah puyuh (Ratriyanto et al., 2017b). 
Tabel 1. Susunan dan Kandungan Nutrien Ransum Basal

\begin{tabular}{|c|c|}
\hline Bahan Pakan & Proporsi $(\mathrm{g} / \mathrm{kg})$ \\
\hline Jagung kuning & 450,0 \\
\hline Bungkil kedelai & 275,0 \\
\hline Bekatul & 56,7 \\
\hline Wheat bran & 50,0 \\
\hline Tepung ikan & 60,0 \\
\hline Minyak kelapa & 33,5 \\
\hline$D L$-metionin & 0,3 \\
\hline Dikalsium fosfat & 6,0 \\
\hline Limestone & 62,5 \\
\hline Premiks vitamin & 2,5 \\
\hline $\mathrm{NaCl}$ & 3,5 \\
\hline \multicolumn{2}{|l|}{ Kandungan nutrien ransum } \\
\hline Energi metabolis $(\mathrm{kcal} / \mathrm{kg})$ & 2.800 \\
\hline Protein kasar $(\mathrm{g} / \mathrm{kg})$ & 187,0 \\
\hline Lemak kasar $(\mathrm{g} / \mathrm{kg})$ & 72,8 \\
\hline Serat kasar $(\mathrm{g} / \mathrm{kg})$ & 39,4 \\
\hline $\mathrm{Abu}(\mathrm{g} / \mathrm{kg})$ & 56,1 \\
\hline Kalsium (g/kg) & 33,0 \\
\hline Fosfor $(\mathrm{g} / \mathrm{kg})$ & 4,3 \\
\hline $\operatorname{Lisin}(\mathrm{g} / \mathrm{kg})$ & 11.8 \\
\hline Metionin $(\mathrm{g} / \mathrm{kg})$ & 4,0 \\
\hline
\end{tabular}

\section{Analisis Data}

Data yang diperoleh dalam penelitian ini dianalisis menggunakan analisis variansi untuk mengetahui adanya pengaruh perlakuan terhadap peubah yang diamati. Apabila terdapat pengaruh perlakuan maka dilanjutkan dengan uji Duncan Multiple Range Test (DMRT) untuk mengetahui perbedaan antar perlakuan (Steel \& Torrie, 1995). Analisis data, termasuk korelasi antarpeubah, dilakukan menggunakan program $\mathrm{R}$ ( $\mathrm{R}$ Core Team, 2015).

\section{HASIL DAN PEMBAHASAN}

\section{Kurva dan Produksi Telur Mingguan}

Kurva produksi telur meningkat dengan cepat setelah mulai peneluran dan mencapai produksi $60 \%$. Selanjutnya produksi meningkat mencapai puncak produksi pada umur 77-98 hari (11-14 minggu), menunjukkan pola produksi telur yang baik (Gambar 1). Pola produksi telur yang baik ditentukan oleh kondisi genetik, faktor lingkungan termasuk pakan dan resistensi terhadap penyakit. Pola produksi ini sesuai dengan penelitian terdahulu pada puyuh Coturnix coturnix japonica (Kaye et al., 2017). Produksi telur dimulai saat dewasa kelamin sekitar umur 6 minggu (Alam et al., 2008; Damme, 2011). Hasil pengamatan yang hampir sama diperoleh pada ayam, yaitu produksi telur meningkat dengan cepat setelah 2 minggu peneluran sampai 8-9 minggu dan mencapai puncak produksi, dan selanjutnya menurun secara bertahap (Pavlidis et al., 2002).

Pola produksi telur dapat ditingkatkan melalui modifikasi faktor nutrisi (Pavlidis et al., 2002). Produksi telur mingguan mulai umur 10 minggu pada puyuh yang mendapat suplementasi betain dan metionin lebih tinggi $(\mathrm{P}<0,05)$ dibanding kontrol (Tabel 2). Suplementasi betain meningkatkan produksi telur mingguan antara 9,4-16,3\%, sedangkan suplementasi metionin meningkatkan produksi telur antara 7,8-15,9\%. Betain dan metionin merupakan donor gugus metil yang mendonasikan gugus metilnya dalam proses transmetilasi dan berperan dalam metabolisme protein dan energi (Ratriyanto et al., 2009). Hasil penelitian ini menunjukkan bahwa betain dan metionin berkontribusi pada meningkatnya sintesis protein (Apicella et al., 2013), yang direpresentasikan dalam performa melalui peningkatan produksi telur (Ratriyanto et al., 2009). Selain itu metionin menurunkan jumlah energi bruto yang diekskresikan, sehingga energi yang diabsorpsi dan digunakan oleh ternak dapat meningkat (Piliang \& Djojosoebagio, 2006). 


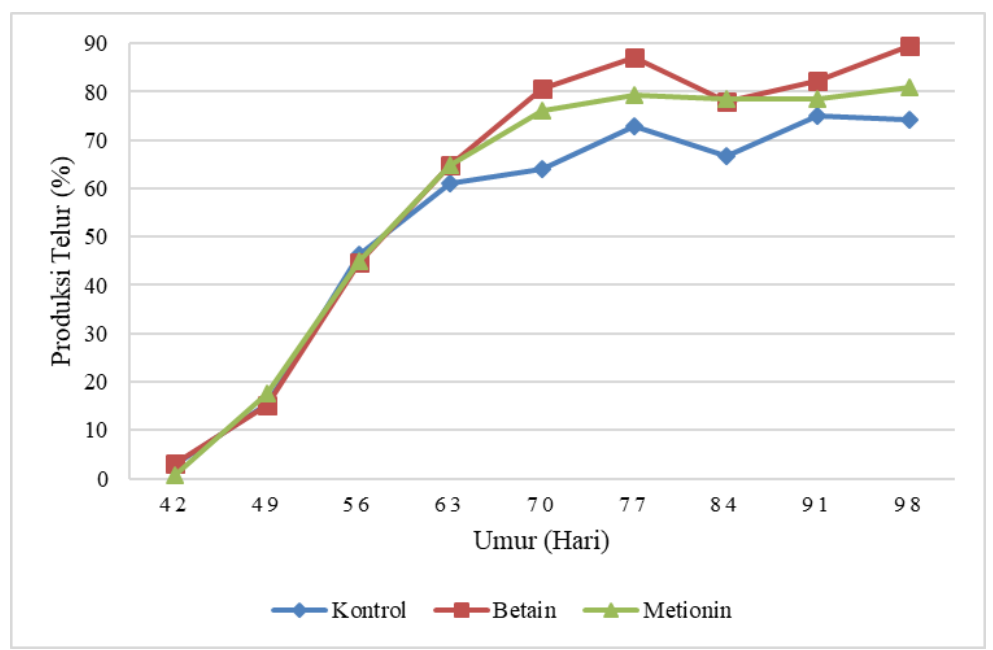

Gambar 1. Kurva Produksi Telur Hari Tertentu (Test Day) Setiap Minggu pada Puyuh (42-98 hari)

Peningkatan produksi telur dalam penelitian ini sejalan dengan penelitian terdahulu pada puyuh (Ratriyanto et al., 2017b) maupun pada ayam petelur (Attia et al., 2016). Suplementasi metionin dalam ransum yang mengandung energi metabolis 2.700 dan $2.900 \mathrm{kcal} / \mathrm{kg}$ serta protein $18 \%$ dapat meningkatkan produksi telur puyuh sebesar 13,9\% (Ratriyanto et al., 2017a). Sementara itu, suplementasi betain dapat meningkatkan produksi telur pada ayam dan puyuh sampai 23,6\% (Attia et al., 2016; Ratriyanto et al., 2017b). Hasil observasi Attia et al. (2016) menunjukkan bahwa peningkatan produksi telur akibat suplementasi betain juga didukung oleh peningkatan perkembangan ovarium dan oviduct serta peningkatan kadar hormon estrogen dan progesteron di dalam darah. Hormon-hormon tersebut berperan dalam regulasi ovulasi dan perkembangan oviduct (Kang et al., 2001).

Tabel 2. Produksi Telur Mingguan

\begin{tabular}{lccccccccc}
\hline \multirow{2}{*}{ Perlakuan } & \multicolumn{8}{c}{ Umur (Minggu) } \\
\cline { 2 - 10 } & 6 & 7 & 8 & 9 & 10 & 11 & 12 & 13 & 14 \\
\hline Kontrol (\%) & 0,80 & 8,36 & 34,57 & 59,03 & $64,71^{\mathrm{b}}$ & $68,21^{\mathrm{b}}$ & $68,16^{\mathrm{b}}$ & $72,17^{\mathrm{b}}$ & $67,00^{\mathrm{b}}$ \\
Betain (\%) & 1,20 & 9,18 & 36,41 & 57,33 & $74,86^{\mathrm{a}}$ & $77,03^{\mathrm{a}}$ & $76,21^{\mathrm{a}}$ & $78,97^{\mathrm{a}}$ & $77,94^{\mathrm{a}}$ \\
Metionin (\%) & 0,40 & 9,12 & 32,04 & 56,25 & $73,94^{\mathrm{a}}$ & $73,91^{\mathrm{ab}}$ & $78,97^{\mathrm{a}}$ & $77,83^{\mathrm{a}}$ & $74,42^{\mathrm{a}}$ \\
\hline Nilai P & 0,54 & 0,89 & 0,25 & 0,25 & 0,02 & 0,02 & $<0,01$ & $<0,01$ & $<0,01$ \\
\hline
\end{tabular}

a, b Superskrip yang berbeda pada kolom yang sama menunjukkan perbedaan yang nyata $(\mathrm{P}<0,05)$

\section{Parameter Produksi Telur}

Suplementasi betain dan metionin dalam ransum dapat meningkatkan $(\mathrm{P}<0,01)$ rerata produksi dari umur 6 sampai 14 minggu antara 9,8 dan 11,8\% (Tabel 3). Sementara itu produksi tertinggi meningkat sebesar $13,5 \%$ pada puyuh yang mendapat suplementasi betain $(\mathrm{P}<0,01)$ dan meningkat sebesar 12,5\% pada puyuh yang mendapat suplementasi metionin $(\mathrm{P}<0,01)$. Peningkatan ini menunjukkan bahwa betain dan metionin berperan dalam metabolisme protein dan energi, yang diindikasikan dengan peningkatan performa produksi (Ratriyanto et al., 2009).

Tabel 3. Parameter Produksi Telur Puyuh yang Disuplementasi Betain dan Metionin

\begin{tabular}{lccccc}
\hline \multirow{2}{*}{ Perlakuan } & $\begin{array}{c}\text { Rerata } \\
\text { Produksi }(\%)\end{array}$ & $\begin{array}{c}\text { Produksi } \\
\text { Tertinggi }(\%)\end{array}$ & $\begin{array}{c}\text { Umur Produksi } \\
10 \% \text { (Hari) }\end{array}$ & $\begin{array}{c}\text { Umur Produksi } \\
50 \% \text { (Hari) }\end{array}$ & $\begin{array}{c}\text { Umur Produksi } \\
\text { Tertinggi (Hari) }\end{array}$ \\
\hline Kontrol & $51,57^{\mathrm{b}}$ & $84,60^{\mathrm{b}}$ & 47,00 & 56,80 & 89,80 \\
Betain & $57,67^{\mathrm{a}}$ & $96,00^{\mathrm{a}}$ & 47,40 & 56,20 & 86,00 \\
Metionin & $56,61^{\mathrm{a}}$ & $95,20^{\mathrm{a}}$ & 47,60 & 58,20 & 80,80 \\
\hline Nilai P & $<0,01$ & $<0,01$ & 0,86 & 0,32 & 0,29 \\
\hline
\end{tabular}

a, b Superskrip yang berbeda pada kolom yang sama menunjukkan perbedaan yang nyata $(\mathrm{P}<0,05)$ 
Produksi telur sebesar 10\% dicapai pada saat puyuh berumur sekitar 47-47,6 hari, sedangkan produksi telur $50 \%$ dicapai pada saat puyuh berumur 56,2-58,2 hari (Tabel 3). Produksi telur tertinggi (puncak produksi) tidak menunjukkan perbedaan $(\mathrm{P}>0,05)$ diantara ketiga perlakuan, walaupun puyuh yang disuplementasi metionin mencapai produksi tertinggi pada umur 80 hari (12 minggu), dibandingkan betain 86 hari dan kontrol 89,8 hari (13 minggu). Hal ini diduga karena tingginya variasi umur pada saat puncak produksi dari tiap unit percobaan (Kaye et al., 2017). Penelitian terdahulu menunjukkan bahwa produksi $50 \%$ dicapai pada umur 45,3 hari (Narinc et al., 2013). Umur pada saat puncak produksi pada penelitian ini lebih cepat daripada penelitian terdahulu pada puyuh yaitu 15 minggu (Narinc et al., 2013). Sementara itu menurut (Kaye et al., 2017) puncak produksi telur puyuh dicapai pada umur 12 minggu. Perbedaan umur puncak produksi ini dapat disebabkan karena perbedaan varitas puyuh dari tiap penelitian.

\section{Korelasi Antar Parameter Produksi Telur}

Rerata produksi telur dan umur produksi tertinggi pada semua perlakuan menunjukkan korelasi negatif (Tabel 4), menunjukkan bahwa semakin cepat produksi tertinggi dicapai maka rerata produksi semakin tinggi. Pada Kontrol dan puyuh yang mendapat suplementasi betain puncak produksi dicapai pada umur yang relatif lebih lambat dibandingkan pada suplementasi metionin. Korelasi antara produksi tertinggi dan umur produksi tertinggi menunjukkan nilai negatif pada ketiga perlakuan, menunjukkan bahwa semakin tinggi puncak produksi dapat dicapai dalam waktu yang lebih cepat. Produksi yang tinggi mengindikasikan banyaknya telur yang dihasilkan diikuti dengan panjangnya clutch. Penelitian terdahulu pada puyuh menunjukkan terdapat korelasi positif antara jumlah telur dengan panjang clutch (Kaye et al., 2017). Panjang clutch pada puyuh bervariasi antara 3 hari sampai 12 hari (Kaye et al., 2017; Pavlidis et al., 2002).

Sementara itu, terdapat korelasi positif antara rerata produksi dengan produksi tertinggi, mengindikasikan bahwa semakin tinggi puncak produksi sejalan dengan meningkatnya rerata produksi telur. Hal ini karena rerata produksi merupakan hasil rata-rata dari produksi keseluruhan, termasuk pada saat puncak produksi. Tingginya puncak produksi berkaitan dengan pola produksi harian atau mingguan, jika produksi harian atau mingguan tinggi maka puncak produksi juga tinggi. Selain itu, lama clutch akan menentukan jumlah telur yang dihasilkan. Menurut Kaye et al. (2017) lama clutch memiliki kontribusi sebesar $72 \%$ terhadap variasi jumlah telur yang dihasilkan, sedangkan 28\% dipengaruhi oleh faktor-faktor lain.

Tabel 4. Korelasi antara berbagai Parameter Produksi Telur

\begin{tabular}{lccc}
\hline Perlakuan & $\begin{array}{c}\text { Rerata Produksi } \sim \text { Umur } \\
\text { Produksi Tertinggi }\end{array}$ & $\begin{array}{c}\text { Produksi Tertinggi } \sim \text { Umur } \\
\text { Produksi Tertinggi }\end{array}$ & $\begin{array}{c}\text { Rerata Produksi } \sim \text { Produksi } \\
\text { Tertinggi }\end{array}$ \\
\hline Kontrol & $-0,42$ & $-0,18$ & 0,71 \\
Betain & $-0,72$ & $-0,76$ & 0,65 \\
Metionin & $-0,43$ & $-0,10$ & 0,52 \\
\hline
\end{tabular}

\section{KESIMPULAN}

Kurva produksi telur meningkat dengan cepat sesaat setelah dimulainya peneluran dan mencapai puncak produksi pada umur 11-14 minggu (7798). Suplementasi betain dan metionin meningkatkan produksi telur mingguan mulai umur 10 minggu, produksi tertinggi dan rerata produksi telur. Korelasi antara puncak produksi dengan rerata produksi bernilai positif, menunjukkan bahwa semakin tinggi puncak produksi maka rerata produksi juga semakin tinggi.

\section{DAFTAR PUSTAKA}

Alam, M.S., Howlider, M.A.R., Mondal, A., Hossain, K., \& Bostami, A.B.M.R. 2008. Pattern of egg production in Japanese quail reared on littered floor and in cage. Bangladesh Research Publications Journal. 1(3), 239-249.

Apicella, J.M., Lee, E.C., Bailey, B.L., Saenz, C., Anderson, J.M., Craig, S.A.S., ... Maresh, C.M. 2013. Betaine supplementation enhances anabolic endocrine and Akt signaling in response to acute bouts of exercise. European 
Journal of Applied Physiology. 113(3), 793802. https://doi.org/10.1007/s00421-0122492-8

Attia, Y.A., Abd-El-Hamid, A.E.E., Abedalla, A.A., Berika, M.A., Al-Harthi, M.A., Kucuk, O., ... Abou-Shehema, B.M. 2016. Laying performance, digestibility and plasma hormones in laying hens exposed to chronic heat stress as affected by betaine, vitamin $\mathrm{C}$, and/or vitamin E supplementation. SpringerPlus. 5(1), 1619. https://doi.org/ 10.1186/s40064-016-3304-0

Damme, K. 2011. Wachteln Zucht und Haltung. Stuttgart: Eugen Ulmer.

Ezzat, W., Shoeib, M.S., Mousa, S.M.M., Bealish, A.M.A., \& Ibrahiem, Z.A. 2011. Impact of betaine, vitamin $\mathrm{C}$ and folic acid supplementations to the diet on productive and reproductive performance of Matrouh poultry. Egyptian Poultry Science. 31(2), 521-537.

Hruby, M., Ombabi, A., \& Schlagheck, A. 2005. Natural betaine maintains layer performance in methionine/choline chloride reduced diets. In Proc. 15th Eur. Symp. on Poultry Nutrition (pp. 507-509). Balatonfured, Hungary.

Kang, W.J., Yun, J.S., Seo, D.S., Hong, K.C., \& Ko, Y. 2001. Relationship among egg productivity, steroid hormones (progesteron and estradiol) and ovary in Korean native chicken. Asian-Australasian Journal of Animal Sciences. 14(7), 922-928.

Kaye, J., Luka, S.J., Akpa, G.N., \& Adeyinka, I.A. 2017. Egg production pattern of Japanese quail (Coturnix coturnix japonica) in northern guinea savannah zone of Nigeria. International Journal of Innovative Research and Advanced Studies. 4(1), 93-97.

Memon, A., Ansari, N.N., Memon, G., Solangi, A.A., \& Qureshi, T.A. 2003. Effect of methionine, lysine and cystine supplementation on the production performance of laying Japanese quails. Journal of Animal and Veterinary Advances. 2(1), 27-29.

Metzler-Zebeli, B.U., Eklund, M., \& Mosenthin, R. 2009. Impact of osmoregulatory and methyl donor functions of betaine on intestinal health and performance in poultry. World's Poultry Science Journal. 65(3), 419-442.
https://doi.org/10.1017/S0043933909000300

Narinc, D., Karaman, E., Aksoy, T., \& Firat, M.Z. 2013. Investigation of nonlinear models to describe long-term egg production in Japanese quail. Poultry Science. 92, 1676-1682. https://doi.org/10.3382/ps.2012-02511

Nutrition Research Council. 1994. Nutrient Requirements of Poultry (9th ed.). Washington DC: National Academic Press. https://doi.org/ $10.17226 / 2114$

Pavlidis, H. O., Price, S. E., \& Siegel, P. B. 2002. Associations between egg production and clutch length in four selected lines of chickens. Journal of Applied Poultry Research. 11(3), 304-307. https://doi.org/10.1093/japr/11.3.304

Piliang, G.W., \& Djojosoebagio, S. 2006. Fisiologi Nutrisi (1st ed.). Bogor: Percetakan Institut Pertanian Bogor.

$\mathrm{R}$ Core Team. 2015. R: A Language and Environment for Statistical Computing. Vienna: $\mathrm{R}$ Foundation for Statistical Computing. https://www.gbif.org/tool/81287/r-alanguage-and-environment-for-statisticalcomputing

Ratriyanto, A., Indreswari, R., \& Nuhriawangsa, A.M.P. 2017. Effects of dietary protein level and betaine supplementation on nutrient digestibility and performance of Japanese quails. Revista Brasileira de Ciencia Avicola. 19(3), 445-454. https://doi.org/10.1590/18069061-2016-0442

Ratriyanto, A., Indreswari, R., Nuhriawangsa, A. M.P., \& Arifin, A.A. 2017. Dietary metabolizable energy and methionine affect performance of quails. In A. Isnansetyo \& $\mathrm{T}$. R. Nuringtyas (Eds.), Proceeding of the 1st International Conference on Tropical Agriculture (pp. 329-335). Cham: Springer International Publishing. https://doi.org/ 10.1007/978-3-319-60363-6

Ratriyanto, A., Mosenthin, R., Bauer, E., \& Eklund, M. 2009. Metabolic, osmoregulatory and nutritional functions of betaine in monogastric animals. Asian-Australasian Journal of Animal Sciences. 22(10), 14611476. https://doi.org/10.5713/ajas.2009.80659 
Sadeghi, R., Pakdel, A., Shahrbabak, M.M., \& Shahrbabak, H.M. 2013. Divergent selection effect on reproductive trait in Japanese quails. Research Journal of Poultry Science. 6(1), 1822.
Steel, R. G. D., \& Torrie, J. H. 1995. Prinsip dan Prosedur Statistik (2nd ed.). Jakarta: Gramedia Pustaka Utama. 